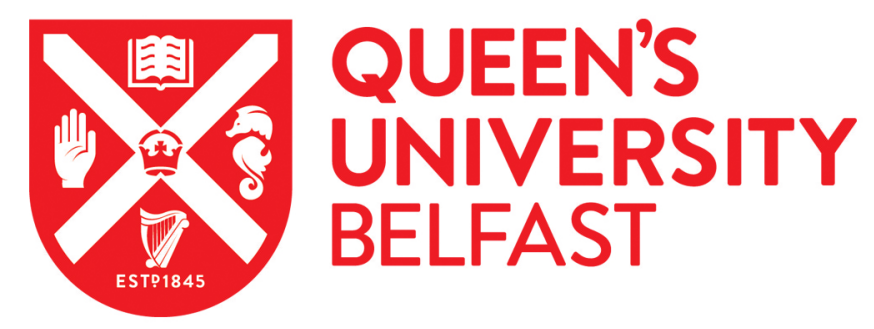

\title{
Crop yields, internal nutrient use efficiency, and changes in soil properties in rice-wheat rotations under non-flooded mulching
} cultivation

Fan, M. S., Liu, X. J., Jiang, R. F., Zhang, F. S., Lu, S. H., Zeng, X. Z., \& Christie, P. (2005). Crop yields, internal nutrient use efficiency, and changes in soil properties in rice-wheat rotations under non-flooded mulching cultivation. Plant and Soil, 277(1-2), 265-276. https://doi.org/10.1007/s11104-005-7459-7

Published in:

Plant and Soil

Queen's University Belfast - Research Portal:

Link to publication record in Queen's University Belfast Research Portal

\section{General rights}

Copyright for the publications made accessible via the Queen's University Belfast Research Portal is retained by the author(s) and / or other copyright owners and it is a condition of accessing these publications that users recognise and abide by the legal requirements associated with these rights.

Take down policy

The Research Portal is Queen's institutional repository that provides access to Queen's research output. Every effort has been made to ensure that content in the Research Portal does not infringe any person's rights, or applicable UK laws. If you discover content in the Research Portal that you believe breaches copyright or violates any law, please contact openaccess@qub.ac.uk. 


\title{
Crop yields, internal nutrient efficiency, and changes in soil properties in rice-wheat rotations under non-flooded mulching cultivation
}

\author{
Mingsheng Fan ${ }^{1}$, Xuejun Liu ${ }^{1}$, Rongfeng Jiang ${ }^{1}$, Fusuo Zhang ${ }^{1,4}$, Shihua Lu ${ }^{1,2}$, \\ Xiangzhong Zeng ${ }^{1,2}$ \& Peter Christie ${ }^{1,3}$ \\ ${ }^{1}$ Department of Plant Nutrition, China Agricultural University, Key Laboratory of Plant Nutrition, Ministry \\ of Agriculture; and Key Laboratory of Plant-Soil Interactions, Ministry of Education, 100094 Beijing, \\ China; ${ }^{2}$ Institute of Soils and Fertilizers, Sichuan Academy of Agricultural Sciences, 610066 Chengdu, China; \\ ${ }^{3}$ Agricultural and Environmental Science Department, Queen's University Belfast, BT9 5PX Belfast, UK. \\ ${ }^{4}$ Corresponding author*
}

Received 3 October 2004. Accepted in revised form 17 May 2005

Key words: internal nutrient efficiency, nutrient balance, rice-wheat cropping system, soil fertility, straw management, water saving

\begin{abstract}
A field experiment was conducted for 5 years to examine the effects of non-flooded mulching cultivation on crop yield, internal nutrient efficiency and soil properties in rice-wheat (R-W) rotations of the Chengdu Plain, southwest China. Compared with traditional flooding (TF), non-flooded plastic film mulching (PM) resulted in 12 and $11 \%$ higher average rice (Oryza sativa L.) yield and system productivity (combined rice and wheat yields), and the trends in rice and wheat (Triticum aestivum L.) yields under PM were stable over time. However, non-flooded wheat straw mulching (SM) decreased average rice yield by $11 \%$ compared with TF, although no significant difference in system productivity was found between SM and TF. Uptakes of N and K by rice under $\mathrm{PM}$ were higher than those under TF and SM, but internal nutrient efficiency was significantly lower $(\mathrm{N})$ or similar $(\mathrm{K})$ under PM compared to SM and TF. This implies that more $\mathrm{N}$ and $\mathrm{K}$ accumulated in rice straw under PM. After 5-year rice-wheat rotation, apparent $\mathrm{P}$ balances $\left(112-160 \mathrm{~kg} \mathrm{ha}^{-1}\right)$ were positive under all three cultivation systems. However, the $\mathrm{K}$ balances were negative under PM $\left(-419 \mathrm{~kg} \mathrm{ha}^{-1}\right)$ and TF $\left(-90 \mathrm{~kg} \mathrm{ha}^{-1}\right)$ compared with SM $\left(45 \mathrm{~kg} \mathrm{ha}^{-1}\right)$. This suggests that higher $\mathrm{K}$ inputs from fertilizer, straw or manure may be necessary, especially under PM. After five rice seasons and four wheat seasons, non-flooded mulching cultivation led to similar (PM) or higher (SM) soil organic carbon (SOC), total N (TN) and alkali hydrolyzable $\mathrm{N}(\mathrm{AH}-\mathrm{N})$ in the top 0-5 and 5-12 cm layers compared with TF. SOC, TN, AH-N and Olsen-P $(\mathrm{OP})$ in the sub-surface layer $(12-24 \mathrm{~cm}$ ) were significantly higher under PM or SM than under TF, indicating that rice under non-flooded mulching conditions may fail to make use of nutrients from the subsoil. Thus, the risk of decline in soil fertility under non-flooded mulching cultivation could be very low if input levels match crop requirements. Our data indicate that PM and SM may be alternative options for farmers using $\mathrm{R}-\mathrm{W}$ rotations for enhancement or maintenance of system productivity and soil fertility.
\end{abstract}

Abbreviations: AH-N - alkali hydrolyzable $\mathrm{N}$ using $1 \mathrm{M} \mathrm{NaOH}$ solution; $\mathrm{EK}$ - exchangeable potassium; $\mathrm{K}$ potassium; $\mathrm{N}$ - nitrogen; $\mathrm{OP}$ - Olsen-P; $\mathrm{P}$ - phosphorus; $\mathrm{PM}$ - plastic film mulching; $\mathrm{R}-\mathrm{W}$ - rice-wheat; $\mathrm{SM}$ wheat straw mulching; $\mathrm{SOC}$-soil organic carbon; $\mathrm{TF}$-traditional flooding cultivation; $\mathrm{TN}$-soil total nitrogen

\footnotetext{
* FAX No: + 86-10-62731016

E-mail: zhangfs@cau.edu.cn
} 


\section{Introduction}

Rice provides a staple food supply for almost half the world's population and about $75 \%$ of world production is from irrigated systems (Maclean et al., 2002). However, fresh water for irrigation is becoming scarce due to increasing competition from urban and industrial demand (Bouman, 2001). This threatens the sustainability of irrigated rice systems and water-saving rice production methods are urgently needed. One promising solution is non-flooded plastic film mulching cultivation, which was introduced into China in the late 1980s. This cultivation technique has led to improved water use efficiency, increased soil temperatures, and improved or maintained rice yields (Fan et al., 2002; Liang et al., 1999; Liu et al., 2003; Wu et al., 1999). The most frequently quoted concerns regarding non-flooded plastic film mulching cultivation are possible declines in soil organic matter or soil nutrients resulting from favorable conditions for soil organic $\mathrm{C}$ decomposition under non-flooded mulching cultivation and the implications for sustainability of rice production. Hu et al. (1999) reported a $8 \%$ decline in soil organic $\mathrm{C}$ and soil total $\mathrm{N}$ in a paddy field under plastic film mulching. However, detailed studies of soil fertility under non-flooded in $\mathrm{R}-\mathrm{W}$ rotation systems, especially long-term consequences, are not available and it is unknown whether stable yields can be attained over time using non-flooded plastic film mulching.

The management of straw and its impact on nutrient cycling and soil fertility are also issues that are important to the sustainability of ricebased production systems. In Asia, farmers either remove straw from their fields for fuel and cattle feed, burn in situ, pile or spread in the field, incorporate into the soil, or use the straw as a mulch for the succeeding crop (Dobermann and Fairhurst, 2000). Straw burning is especially popular for wheat straw disposal in rice-wheat rotations in China because of the short turnaround time between the wheat harvest and rice transplanting, and advantages of this method include pest and disease control and saving of labor and energy (Ponnamperuma, 1984). However, estimated losses are up to $80 \%$ of $\mathrm{N}$ (Raison, 1979), $25 \%$ of $\mathrm{P}$ and $21 \%$ of K (Ponnamperuma, 1984) and 4-60\% of S (Lefroy et al.,
1994) in addition to the problem of air pollution. Burning of straw must be avoided for environmental reasons. One possible solution would be to use the wheat straw as a soil mulch material in non-flooded rice cultivation systems. However, experimental results have revealed site-to-site differences in response of rice to non-flooded straw mulching cultivation. For example, rice grain yields under straw mulching cultivation were comparable to those under traditional flooded cultivation at Guangzhou and Jiangsu provinces in China (Fan et al., 2002; Liang et al., 1999). In contrast, Wang et al. (2002) reported that wheat straw mulching cultivation inhibited rice growth at early stages with a subsequent decline in rice yield. All of these studies, however, were conducted over relatively short-time periods of about 1 or 2 years. A previous study summarized effects of straw incorporation on crop yield trends and profitability in long-term experiments with rice-rice and $\mathrm{R}-\mathrm{W}$ systems (Dawe et al., 2003). However, the cumulative effects of straw returned as a mulching material on soil fertility, crop yields and the sustainability of $\mathrm{R}-\mathrm{W}$ rotation systems under non-flooded cultivation conditions remain poorly understood.

In this paper, we report on a field experiment conducted on non-flooded mulching cultivation (plastic film mulching and wheat straw mulching) of rice in $\mathrm{R}-\mathrm{W}$ systems over a period of 5 years. The aims were to: (i) understand yield trends, internal nutrient efficiency (NPK), and nutrient (PK) balance, and (ii) compare a range of soil properties $(\mathrm{pH}$, organic $\mathrm{C}$, total $\mathrm{N}$, and available NPK) in both topsoil and subsoil under nonflooded mulching cultivation with those under traditional flooded cultivation. Some results from the first three years of the study have been reported by Liu et al. (2003).

\section{Materials and methods}

\section{Field experiment}

The field experiment, which has been in progress since 1999, was previously described by Liu et al. (2003). The experimental site $\left(30^{\circ} 42^{\prime} \mathrm{N}, 103^{\circ} 50^{\prime} \mathrm{E}\right.$ and $539 \mathrm{~m}$ elevation) is located at Wenjiang county near the center of Chengdu Plain. The region is classified as humid sub-tropical with a 
monsoon climate. Average annual rainfall is $947 \mathrm{~mm}$. The soil is classified as a Stagnic Anthrosol (Fluvaquent) developed from alluvial deposits of the Minjiang river (containing free $\mathrm{CaCO}_{3}$ ). The top $20 \mathrm{~cm}$ of the sandy loam contained $12.3 \mathrm{~g} \mathrm{~kg}^{-1}$ soil organic $\mathrm{C}$ (SOC), $1.70 \mathrm{~g} \mathrm{~kg}^{-1}$ total $\mathrm{N}$ (TN), $5.2 \mathrm{mg} \mathrm{kg}^{-1}$ Olsen-P (OP), and $37.9 \mathrm{mg} \mathrm{kg}^{-1}$ exchangeable $\mathrm{K}$ (EK) and had a $\mathrm{pH}$ value (in water) of 7.8 at the start of the experiment in 1999.

The field experiment comprised six treatments in a randomized block design with three replicates and a plot size of $3 \times 8 \mathrm{~m}$. For the present study, however, only data from the following three treatments were used: traditional flooding cultivation (TF) as control, and plastic film mulching (PM) and straw mulching (SM) as the two non-flooded mulching cultivation treatments. In each rice season, all the $\mathrm{N}, \mathrm{P}$, and $\mathrm{K}$ fertilizers $\left(150 \mathrm{~kg} \mathrm{~N} \mathrm{ha}^{-1}\right.$ as urea, $40 \mathrm{~kg} \mathrm{P} \mathrm{ha}^{-1}$ as calcium superphosphate and $75 \mathrm{~kg} \mathrm{~K} \mathrm{ha}^{-1}$ as potassium sulfate or potassium chloride) were broadcast and incorporated into the seedbed of all three treatments prior to transplanting of rice. In the wheat season, the $\mathrm{P}$ and $\mathrm{K}$ fertilizers (26 kg P ha ${ }^{-1}$ as calcium superphosphate, $50 \mathrm{~kg}$ $\mathrm{K} \mathrm{ha}^{-1}$ as potassium sulfate) and $50 \%$ of the $\mathrm{N}$ fertilizer $\left(120 \mathrm{~kg} \mathrm{ha}^{-1}\right.$ as urea) were applied to the seedbed of all plots just before sowing and the remaining half of the $\mathrm{N}$ fertilizer was broadcast in early February (at the booting stage of wheat).

Traditional flooding and non-flooded plots were separated by a $2-\mathrm{m}$ wide alley using plastic film inserted into the soil to a depth of $60 \mathrm{~cm}$. Plastic film, $0.005-\mathrm{mm}$ thick and $1.7-\mathrm{m}$ wide, was used to cover the soil in the PM treatment. Wheat straw, harvested from the same field in the wheat season (about $5250 \mathrm{~kg} \mathrm{DM} \mathrm{ha}{ }^{-1}$ containing $26 \mathrm{~kg} \mathrm{~N} \mathrm{ha}{ }^{-1}, 5 \mathrm{~kg} \mathrm{P} \mathrm{ha} a^{-1}$ and $58 \mathrm{~kg}$ $\mathrm{K} \mathrm{ha}^{-1}$ on average) was used to cover the soil in the SM treatment. Every year, rice (Oryza sativa L.) was transplanted in late May using two seedlings per hill at $20 \times 28 \mathrm{~cm}$ spacing. The hybrid rice varieties used were Gangyou 527 in 1999 and 2000, Xiangyou 1 in 2001 and 2002, and Xiangyou 2 in 2003. Rice was harvested from ground level manually by sickle in mid September. After the rice harvest each year, wheat was sown with zero tillage and the removal of rice straw according to conventional agricultural practice. Most of the residual plastic film was removed from the field before sowing the wheat in the PM treatment. In early (2-6) November, the wheat variety 'SW3243', supplied by the Institute of Crop Science, Sichuan Academy of Agriculture Science was sown directly into the soil at two spacings of $10 \times 15 \mathrm{~cm}$ and $10 \times 25 \mathrm{~cm}$ as bunch planting. The wheat was harvested in mid- (10-17) May the following year.

In the TF treatment, plots were irrigated every 3-5 days to maintain a $3-\mathrm{cm}$ water level until 2 weeks before the rice harvest in line with traditional farming practice. Limited irrigation was provided only from transplanting to late tillage stage in all non-flooded mulching plots, depending on the weather conditions. No irrigation was supplied in the wheat season.

\section{Soil and plant analysis}

After the rice harvest in September 2003, soil samples were taken from the $0-5,5-12$, and 12 $24 \mathrm{~cm}$ soil layers in each plot at three locations and mixed to give composite samples. Air-dried sub-samples were analyzed for $\mathrm{pH}$ (1:1 in water), SOC $\left(\mathrm{K}_{2} \mathrm{Cr}_{2} \mathrm{O}_{7}-\mathrm{H}_{2} \mathrm{SO}_{4}\right)$, TN (micro-Kjeldahl), OP $\left(0.5 M \mathrm{NaHCO}_{3}\right)$, and EK $\left(\mathrm{NH}_{4} \mathrm{OAc}\right)$ using the methods described by Sparks et al. (1996) and for alkali hydrolyzable $\mathrm{N}(\mathrm{AH}-\mathrm{N}, \mathrm{NaOH})$ using the method described by Cornfield (1960). Grain yields were determined by harvesting $8 \mathrm{~m}^{2}$ (rice) or $6 \mathrm{~m}^{2}$ (wheat) of each plot at harvestable maturity. Straw yields were estimated from oven-dry grain yield and the grain-to-straw ratio of six hills (rice) or $0.2 \mathrm{~m}^{2}$ area (wheat) plant samples taken at harvestable maturity. All directly measured plant parameters are based on oven-dried plant material with a residual moisture content of ca. $3 \%$ except for rice grain yield which was adjusted to $140 \mathrm{~g} \mathrm{~kg}^{-1}$ moisture content. The ovendried plant sub-samples (grain and straw) from the 6-hill or $0.2 \mathrm{~m}^{2}$ area samples were then ground and analyzed for $\mathrm{N}$ by the micro-Kjeldahl procedure, for $\mathrm{P}$ by the vanadomolybdate method, and for $\mathrm{K}$ by flame photometry after wet digestion with $\mathrm{H}_{2} \mathrm{SO}_{4}$ and $\mathrm{H}_{2} \mathrm{O}_{2}$. NPK uptakes were calculated as the product of concentration and yield of the aboveground parts of the plants on a dry matter basis. 


\section{Internal nutrient efficiency and apparent nutrient balance}

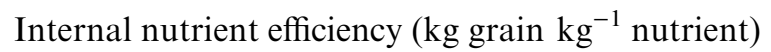
can be defined as ratio of grain yield over total plant nutrient uptake with the aboveground biomass (Witt et al., 1999). This reflects the efficiency in utilization of the nutrients actually absorbed and approximates the effects of plant factors.

The apparent $\mathrm{P}$ and $\mathrm{K}$ balances were calculated by difference between the inputs and outputs. The calculations were made as follows:

$\mathrm{P}$ balance $=(\mathrm{P}$ addition from fertilizer + straw + seeds/seedlings $)-($ P removal by crop)

$\mathrm{K}$ balance $=(\mathrm{K}$ addition from fertilizer + straw + irrigation water + rain + seeds/seedlings) - ( $\mathrm{K}$ removal by plant + losses of $\mathrm{K}$ )

The $\mathrm{P}$ and $\mathrm{K}$ contents in mineral fertilizer and straw were measured directly and no $\mathrm{P}$ was detected in rainwater or irrigation water. $\mathrm{K}$ input from irrigation water was computed from the estimated total amount of applied irrigation water $(5500 \mathrm{~mm}$ in $\mathrm{TF}$ and $500 \mathrm{~mm}$ in $\mathrm{PM}$ and $\mathrm{SM}$ ) in five rice seasons and measurements of $\mathrm{K}$ in irrigation water which were done at 10-day intervals in the 2004 rice season. Rainwater contributions of $8.14 \mathrm{~kg} \mathrm{~K}^{-1}$ year $^{-1}$ were based on data reported by Shi (2003) for Chongqing in southwest China. The amounts of $\mathrm{P}$ and $\mathrm{K}$ added to the soil with rice seedlings/wheat seeds were estimated as the product of the concentration and weight of the seedlings/seeds on a dry matter basis.
Leaching loss of $\mathrm{K}$ was estimated to be $3.1 \mathrm{~kg} \mathrm{ha}^{-1}$ year $^{-1}$ for PM, $3.6 \mathrm{~kg} \mathrm{ha}^{-1}$ year $^{-1}$ for $\mathrm{SM}$, and $14.7 \mathrm{~kg} \mathrm{ha}^{-1}$ year $^{-1}$ for TF, measured in the 1999 rice season (Wang, 2001). We assumed that $\mathrm{P}$ losses through leaching or otherwise from the soil-plant system were negligible.

\section{Climatic conditions}

Temperature, sunshine hours and rainfall data are listed as averages over the five rotation periods from 1999 to 2004 in Figure 1. While the timing of the rainy season is relatively predictable, there was considerable year-to-year variation in the amount, intensity, and distribution of rain and sunshine hours. The mean temperature of the five experimental years ranged from $5.9^{\circ} \mathrm{C}$ in January to $26{ }^{\circ} \mathrm{C}$ in August. There was also relatively good year-to-year consistency for the monthly mean temperature despite a hot period commencing in August 2001 (data not shown).

\section{Statistical analysis}

Analysis of variance (ANOVA) was performed on a fully randomized plot design to test for significance of treatments and means were compared by least significance difference (LSD) at the 5\% level (SAS, 1996). Linear regression analysis of grain yields across years was performed to determine trends. The probability values on the slope indicated the level of significance of observed changes in yield.

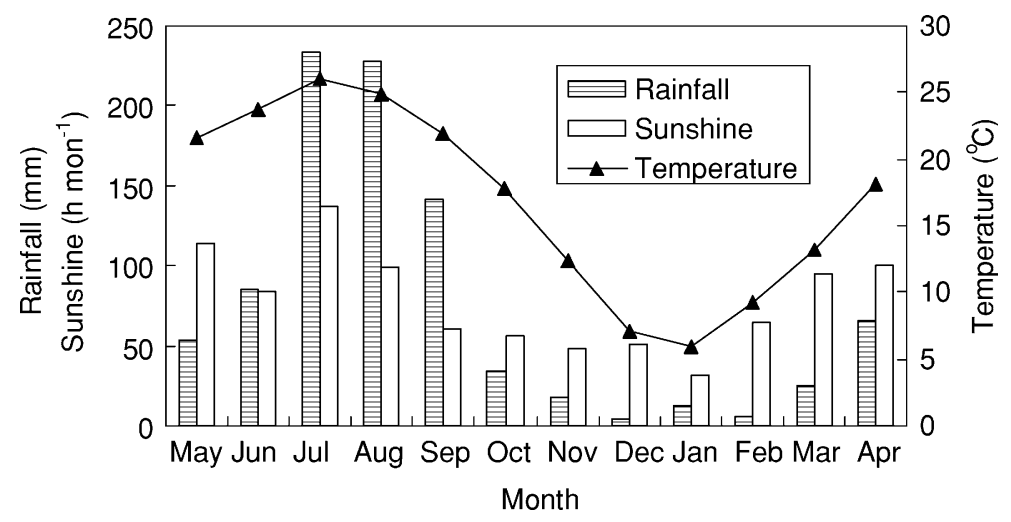

Figure 1. Mean temperature, rainfall, and sunshine hours of five rotation periods (1999-2004) for R-W rotation on Chengdu plain, southwest China. Sunshine hours and rainfall data are monthly totals. Temperatures are the monthly averages. 


\section{Results}

\section{Grain yields}

The grain yields of rice and wheat in the different mulching cultivation systems over the five years of the experiment are shown in Table 1 and Figures 2 and 3. Rice grain yields followed the sequence of $\mathrm{PM}>\mathrm{TF}>\mathrm{SM}$ across the years, and significant differences occurred among the three systems during the first three years, while the yields of the three cropping systems were similar during the final two years (Table 1 and Figure 2). Compared with TF, PM resulted in $12 \%$ higher average rice grain yield, while SM decreased average rice yield by $11 \%$. Unlike rice, wheat yields were not significantly affected by the treatments over the five experimental years (Table 1 and Figure 3 ). There were also no signifi- cant differences in the average wheat yields among three cultivation systems $\left(4.3 \mathrm{tha}^{-1}\right.$ for TF, $5.3 \mathrm{tha}^{-1}$ for PM, and $5.2 \mathrm{t} \mathrm{ha}^{-1}$ for SM) (Table 1). This suggests that non-flooded mulching cultivation in the preceding rice season had no residual effect on the succeeding wheat in the present study. Though wheat yields declined over time, the decline was nearly significant for PM and SM. System productivity (combined rice and wheat grain yields) under PM $\left(12.1 \mathrm{t} \mathrm{ha}^{-1}\right)$ was higher than under TF $\left(10.9 \mathrm{t} \mathrm{ha}^{-1}\right)$ or SM $\left(10.6 \mathrm{t} \mathrm{ha}^{-1}\right.$ ) (Table 1). Such trends may be ascribed to the effect of increased rice grain yield under PM.

Figure 3 shows changes in the grain yield of rice and wheat over time. The yield changes under the three cultivation systems ranged from -78 to $158 \mathrm{~kg} \mathrm{ha}^{-1}$ for rice, and from -325 to $-257 \mathrm{~kg} \mathrm{ha}^{-1}$ for wheat, but they were not significantly different

Table 1. Mean yield, change in yield, $P$-value, and $R^{2}$ in a 5 -year rice-wheat rotation experiment as affected by non-flooded mulching cultivation

\begin{tabular}{|c|c|c|c|c|c|c|c|c|c|}
\hline \multirow[t]{2}{*}{ Cultivation system ${ }^{a}$} & \multicolumn{4}{|l|}{ Rice (R) } & \multicolumn{4}{|l|}{ Wheat (W) } & \multirow{2}{*}{$\begin{array}{l}\text { System } \\
\mathrm{R}+\mathrm{W}^{\mathrm{b}} \\
\left(\mathrm{kg} \mathrm{ha}^{-1}\right)\end{array}$} \\
\hline & $\begin{array}{l}\text { Mean Yield } \\
\left(\mathrm{kg} \mathrm{ha}^{-1}\right)\end{array}$ & $\begin{array}{l}\text { Yield change } \\
\left(\mathrm{kg} \mathrm{ha}^{-1}\right)\end{array}$ & $P$-value ${ }^{\mathrm{d}}$ & $R^{2 \mathrm{e}}$ & $\begin{array}{l}\text { Mean Yield } \\
\left(\mathrm{kg} \mathrm{ha}^{-1}\right)\end{array}$ & $\begin{array}{l}\text { Yield change } \\
\left(\mathrm{kg} \mathrm{ha}^{-1}\right)\end{array}$ & $P$-value & $R^{2}$ & \\
\hline $\mathrm{TF}$ & $6013^{\mathrm{b}}$ & 8 & 0.970 & 0.001 & $4920^{\mathrm{a}}$ & -325 & 0.189 & 0.637 & $10933^{\mathrm{b}}$ \\
\hline $\mathrm{PM}$ & $6763^{\mathrm{a}}$ & -79 & 0.685 & 0.063 & $5325^{\mathrm{a}}$ & -259 & 0.098 & 0.654 & $12088^{\mathrm{a}}$ \\
\hline SM & $5381^{\mathrm{c}}$ & 158 & 0.247 & 0.407 & $5201^{\mathrm{a}}$ & -257 & 0.077 & 0.701 & $10583^{\mathrm{b}}$ \\
\hline
\end{tabular}

${ }^{\text {a}} \mathrm{SM}$ : Wheat straw mulching; TF: traditional flooding; PM: plastic film mulching.

${ }^{\mathrm{b}}$ Within each column, means followed by the same letter are not significantly different at the $5 \%$ level.

'Slope value.

${ }^{\mathrm{d}}$ Level of significance of yield change.

${ }^{\mathrm{e}}$ Regression coefficient of yield change.

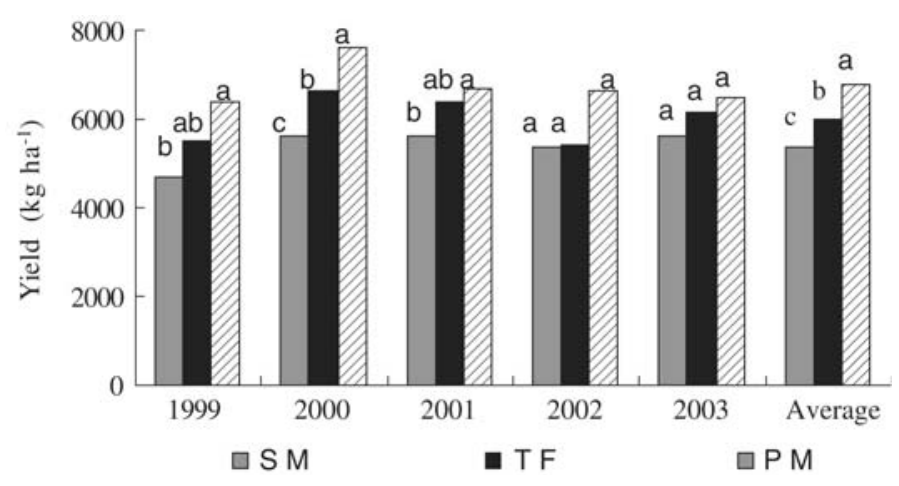

Figure 2. Effects of cultivation type on rice grain yields during the experimental period from 1999 to 2003 ( $\mathrm{kg} \mathrm{ha}^{-1}$ ). SM: Wheat straw mulching; TF: traditional flooding; PM: plastic film mulching. Within each season, values with the same letters are not significantly different by LSD at the $5 \%$ level across the three cultivation systems. 

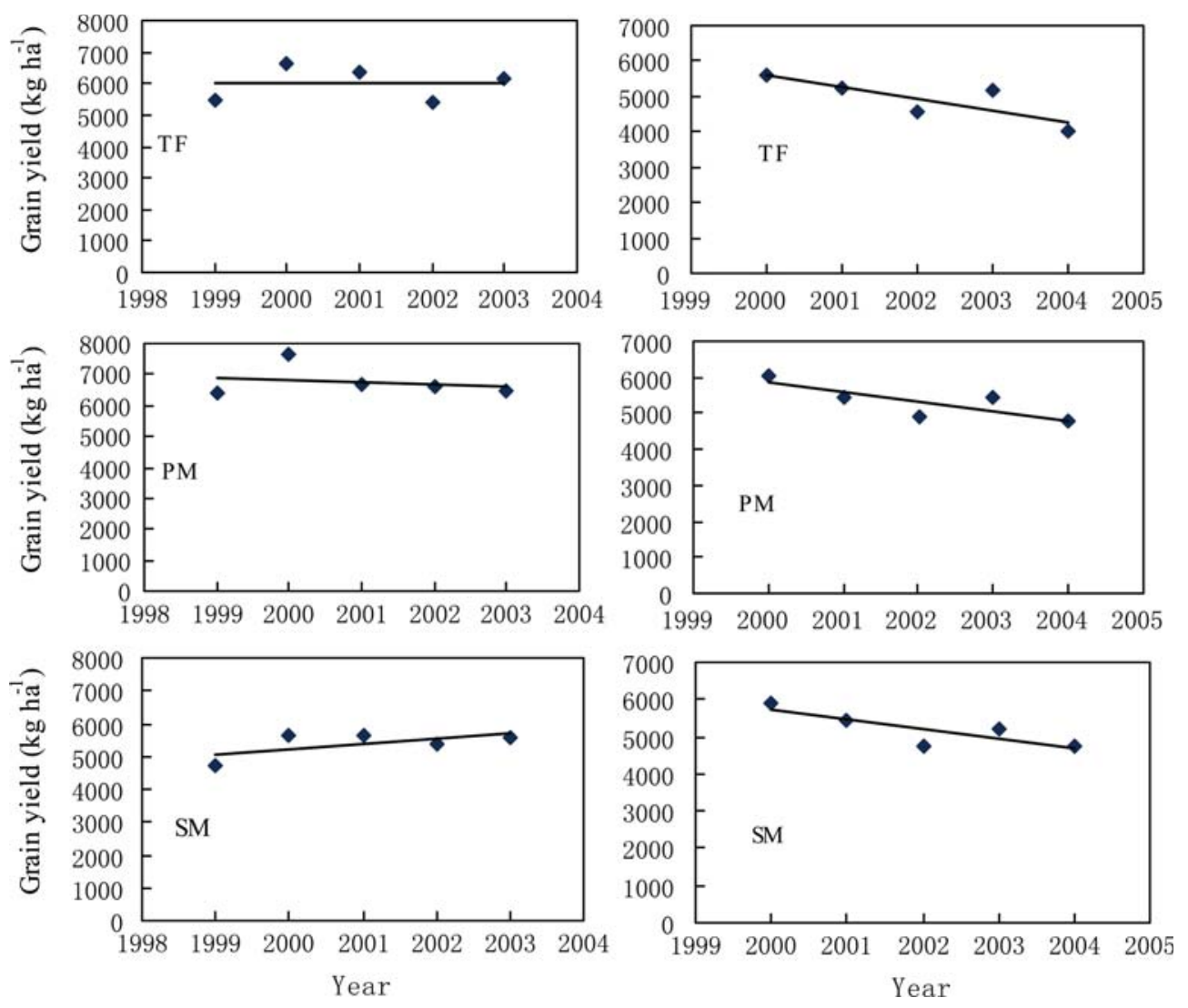

Figure 3. Trends in yields of rice and wheat crops with TF, PM and SM treatments. See Table 1 for regression coefficients. TF: traditional flooding; SM: Wheat straw mulching; PM: plastic film mulching.

$(P>0.05$, Table 1$)$. The greater rate of change in wheat yield may be linked to the high initial wheat yield.

\section{Nutrient uptake and internal nutrient efficiency}

The average nutrient uptake of rice aboveground parts and internal nutrient efficiency as affected by non-flooded mulching cultivation are shown in Table 2. PM led to significantly higher $\mathrm{N}$ $\left(115 \mathrm{~kg} \mathrm{ha}^{-1}\right.$ year $\left.^{-1}\right)$ and $\mathrm{K}\left(150 \mathrm{~kg} \mathrm{ha}^{-1}\right.$ year $\left.^{-1}\right)$ uptake by rice compared with TF and SM. This resulted mainly from higher aboveground biomass under PM than under TF or SM (Liu et al., 2003). However, internal efficiency of $\mathrm{N}$ was significantly lower under PM $\left(59 \mathrm{~kg} \mathrm{~kg}^{-1}\right)$ than under TF $\left(65 \mathrm{~kg} \mathrm{~kg}^{-1}\right)$ or SM $\left(64 \mathrm{~kg} \mathrm{~kg}^{-1}\right)$, and internal efficiency of $\mathrm{K}\left(45-49 \mathrm{~kg} \mathrm{~kg}^{-1}\right)$ was similar among the three cultivation systems
(Table 2). These results suggest that these was a large increase in $\mathrm{N}$ and $\mathrm{K}$ uptake under $\mathrm{PM}$ than under SM and TF, but no proportional increase in yield because of other yield-limiting factors. Mean phosphorus uptake under SM was significantly lower than under TF or PM but in the fifth rice season TF resulted in a larger $\mathrm{P}$ uptake $\left(31.4 \mathrm{~kg} \mathrm{ha}^{-1}\right)$ compared with PM $\left(20.3 \mathrm{~kg} \mathrm{ha}^{-1}\right)$ or SM $\left(17.9 \mathrm{~kg} \mathrm{ha}^{-1}\right.$ ) (Figure 4). Mean internal efficiency of $\mathrm{P}$ was not statistically different among the three cultivation methods. The internal efficiencies of $\mathrm{N}, \mathrm{P}$ and $\mathrm{K}$ in the present study were not identical to the average values found in Asia (59 kg grain kg-1 N; $354 \mathrm{~kg}$ grain $\mathrm{kg}^{-1} \mathrm{P}$; $64 \mathrm{~kg}$ grain $\mathrm{kg}^{-1} \mathrm{~K}$ ) (Witt et al., 1999) and Sahelian West Africa $(70.8 \mathrm{~kg}$ grain $\mathrm{kg}^{-1} \mathrm{~N} ; 331.4 \mathrm{~kg}$ grain $\mathrm{kg}^{-1} \mathrm{P} ; 55.1 \mathrm{~kg}$ grain $\mathrm{kg}^{-1} \mathrm{~K}$ ) (Haefele et al., 2003) but still fell within the minimum and maximum values. 
Table 2. Mean nutrient (NPK) uptake and internal nutrient efficiency by rice across five experimental years (1999-2003)

\begin{tabular}{|c|c|c|c|c|c|c|}
\hline \multirow[t]{2}{*}{ Cultivation system $^{\mathrm{a}}$} & \multicolumn{3}{|c|}{ Nutrient uptake $\left(\mathrm{kg} \mathrm{ha}^{-1}\right.$ year $\left.^{-1}\right)$} & \multicolumn{3}{|c|}{ Internal nutrient efficiency $\left(\mathrm{kg} \mathrm{kg}^{-1}\right)$} \\
\hline & $\mathrm{N}$ & $\mathrm{P}$ & $\mathrm{K}$ & $\mathrm{N}$ & $\mathrm{P}$ & $\mathrm{K}$ \\
\hline $\mathrm{TF}$ & 93 & 23 & 123 & 65 & 261 & 49 \\
\hline PM & 115 & 23 & 150 & 59 & 294 & 45 \\
\hline SM & 85 & 19 & 118 & 64 & 280 & 46 \\
\hline Significance & $* *$ & $*$ & $*$ & $*$ & NS & NS \\
\hline $\operatorname{LSD}^{\mathrm{b}}$ & 13 & 2 & 24 & 4.4 & & \\
\hline
\end{tabular}

${ }^{a}$ SM: Wheat straw mulching; TF: traditional flooding; PM: plastic film mulching.

${ }^{\mathrm{b}}$ Least significant difference at the $5 \%$ level.

***Significant at $P<0.05$ and 0.01 , respectively; NS, Not significant.

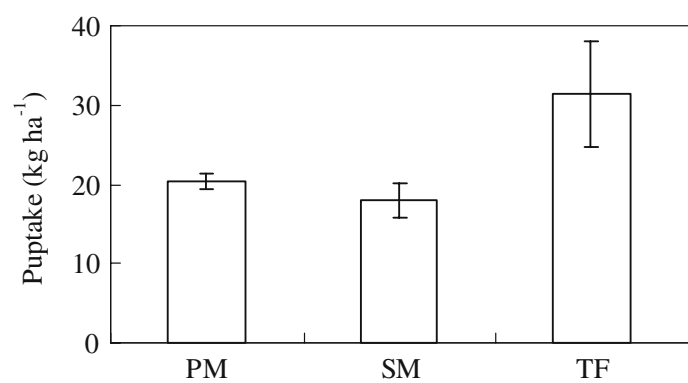

Figure 4. Effect of cultivation type on $\mathrm{P}$ uptake by rice in the fifth rice season. TF: traditional flooding; SM: Wheat straw mulching; PM: plastic film mulching.

\section{Nutrient balance}

The total apparent nutrient (PK) balance over the five experimental years in the three cultivation systems are presented in Tables 3 and 4. The apparent $\mathrm{P}$ balance ranged from 112 to $160 \mathrm{~kg} \mathrm{ha}^{-1}$. The highest $\mathrm{P}$ surplus $\left(160 \mathrm{~kg} \mathrm{ha}^{-1}\right)$ was observed under SM due to the highest $\mathrm{P}$ input and the lowest $\mathrm{P}$ output (Table 3). In con- trast to the positive balance of $\mathrm{P}$, apparent $\mathrm{K}$ balances under $\mathrm{PM}$ and $\mathrm{TF}$ were negative (Table 4). This implies that current fertilizer $\mathrm{K}$ application rates were not sufficient to match $\mathrm{K}$ removal under PM and TF. The negative $\mathrm{K}$ balance under PM $\left(-419 \mathrm{~kg} \mathrm{ha}^{-1}\right)$ was higher than under TF $\left(-90 \mathrm{~kg} \mathrm{ha}^{-1}\right)$ due to the higher $\mathrm{K}$ output (uptake by the crop) and lower input for irrigation water under PM than under TF. Total K input was comparable to or even higher than the $\mathrm{K}$ output (uptake by crops) under SM. Hence, the net $\mathrm{K}$ balance under SM was positive $\left(45 \mathrm{~kg} \mathrm{ha}^{-1}\right)$. Clearly, straw management in the rice systems played a major role in soil nutrient balance.

\section{Soil properties}

Selected soil properties at depths $0-5$ and 5$12 \mathrm{~cm}$ as affected by non-flooded mulching cultivation after the fifth rice season are presented in Table 5. Soil $\mathrm{pH}$ and alkali hydrolyzable $\mathrm{N}$ at 0 $12 \mathrm{~cm}$ soil depth were not significantly different

Table 3. Apparent $\mathrm{P}$ balance in a 5-year rice-wheat rotation experiment as affected by non-flooded mulching cultivation

\begin{tabular}{|c|c|c|c|c|c|c|c|c|}
\hline \multirow[t]{2}{*}{ Cultivation system $^{\mathrm{a}}$} & \multicolumn{4}{|l|}{ Input } & \multicolumn{3}{|l|}{ Output } & \multirow[t]{2}{*}{ Balance (1-2) $\left(\mathrm{kg} \mathrm{ha}^{-1}\right)$} \\
\hline & $\begin{array}{l}\text { Fertilizer } \\
\left(\mathrm{kg} \mathrm{ha}^{-1}\right)\end{array}$ & $\begin{array}{l}\text { Straw } \\
\left(\mathrm{kg} \mathrm{ha}^{-1}\right)\end{array}$ & $\begin{array}{l}\mathrm{S}^{\mathrm{b}} \\
\left(\mathrm{kg} \mathrm{ha}^{-1}\right)\end{array}$ & $\begin{array}{l}\text { Total (1) } \\
\left(\mathrm{kg} \mathrm{ha}^{-1}\right)\end{array}$ & $\begin{array}{l}\mathrm{R}^{\mathrm{c}} \\
\left(\mathrm{kg} \mathrm{ha}^{-1}\right)\end{array}$ & $\begin{array}{l}\mathrm{W}^{\mathrm{d}} \\
\left(\mathrm{kg} \mathrm{ha}^{-1}\right)\end{array}$ & $\begin{array}{l}\text { Total (2) } \\
\left(\mathrm{kg} \mathrm{ha}^{-1}\right)\end{array}$ & \\
\hline $\mathrm{TF}$ & 330 & 0 & 10 & 340 & 114 & 112 & 226 & 114 \\
\hline PM & 330 & 0 & 10 & 340 & 115 & 113 & 228 & 112 \\
\hline SM & 330 & 25 & 10 & 365 & 94 & 111 & 205 & 160 \\
\hline
\end{tabular}

${ }^{\text {a}} \mathrm{SM}$ : Wheat straw mulching; TF: traditional flooding; PM: plastic film mulching.

${ }^{\mathrm{b}} \mathrm{P}$ input from rice seedlings $\left(7.9 \mathrm{~kg} \mathrm{ha}^{-1}\right)$ and wheat seeds $\left(2.1 \mathrm{~kg} \mathrm{ha}^{-1}\right)$.

${ }^{\mathrm{c}} \mathrm{P}$ uptake by rice.

${ }^{\mathrm{d}} \mathrm{P}$ uptake by wheat. 
Table 4. Apparent $\mathrm{K}$ balance in a 5-year rice-wheat rotation experiment as affected by non-flooded mulching cultivation

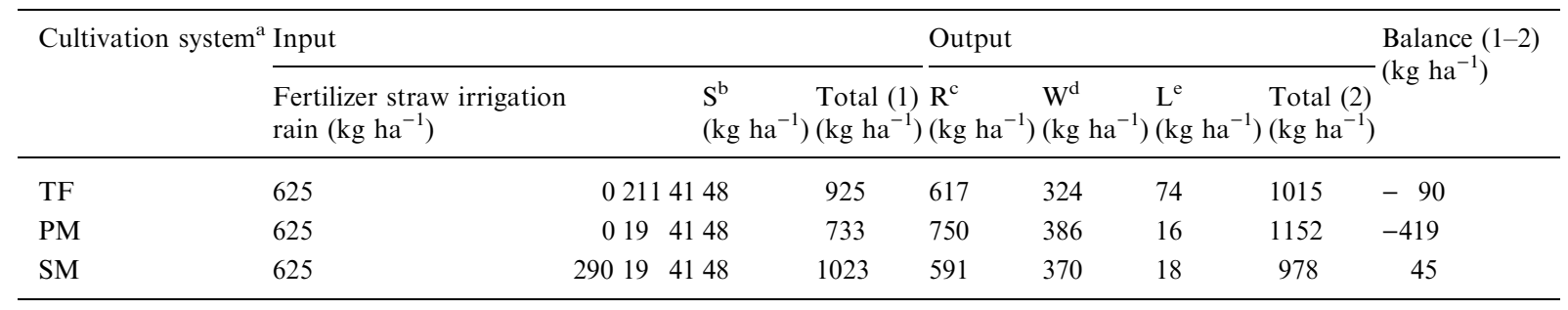

a SM: Wheat straw mulching; TF: traditional flooding; PM: plastic film mulching.

${ }^{\mathrm{b}} \mathrm{K}$ input from rice seedlings $\left(45.1 \mathrm{~kg} \mathrm{ha}^{-1}\right)$ and wheat seeds $\left(2.9 \mathrm{~kg} \mathrm{ha}^{-1}\right)$.

${ }^{\mathrm{c}} \mathrm{K}$ uptake by rice.

${ }^{\mathrm{d}} \mathrm{K}$ uptake by wheat.

${ }^{\mathrm{e}} \mathrm{K}$ leaching.

Table 5. Selected soil properties from the soil profile $(0-5,5-12$ and $12-24 \mathrm{~cm}$ depth) as affected by non-flooded mulching cultivation after the fifth rice season

\begin{tabular}{|c|c|c|c|c|c|c|}
\hline Cultivation system $^{a}$ & $\mathrm{pH}\left(\mathrm{H}_{2} \mathrm{O}, 1: 1\right)$ & $\operatorname{SOC}\left(\mathrm{g} \mathrm{kg}^{-1}\right)$ & $\mathrm{TN}\left(\mathrm{g} \mathrm{kg}^{-1}\right)$ & $\mathrm{AH}-\mathrm{N}\left(\mathrm{mg} \mathrm{kg}^{-1}\right)$ & $\mathrm{OP}\left(\mathrm{mg} \mathrm{kg}^{-1}\right)$ & $\mathrm{EK}\left(\mathrm{mg} \mathrm{kg}^{-1}\right)$ \\
\hline \multicolumn{7}{|l|}{$0-5 \mathrm{~cm}$} \\
\hline TF & 7.1 & 17.0 & 1.80 & 133 & 8.25 & 34.4 \\
\hline PM & 7.0 & 17.2 & 1.81 & 136 & 11.6 & 35.7 \\
\hline SM & 6.8 & 19.2 & 1.93 & 143 & 14.1 & 50.5 \\
\hline Significance & NS & $* *$ & $*$ & NS & $* *$ & $* *$ \\
\hline $\mathrm{LSD}^{\mathrm{b}}$ & & 1.19 & 0.10 & & 1.04 & 7.09 \\
\hline \multicolumn{7}{|l|}{$5-12 \mathrm{~cm}$} \\
\hline TF & 7.6 & 16.3 & 1.56 & 124 & 6.83 & 27.7 \\
\hline PM & 7.4 & 16.2 & 1.71 & 133 & 7.91 & 29.0 \\
\hline SM & 7.2 & 17.7 & 1.63 & 134 & 10.6 & 38.4 \\
\hline Significance & NS & $*$ & NS & NS & $* *$ & $* *$ \\
\hline $\operatorname{LSD}(5 \%)$ & & 1.38 & & & 0.96 & 6.00 \\
\hline \multicolumn{7}{|l|}{$12-24 \mathrm{~cm}$} \\
\hline $\mathrm{TF}$ & 7.4 & 11.0 & 1.05 & 77.5 & 1.44 & 26.3 \\
\hline PM & 7.1 & 12.5 & 1.23 & 94.2 & 2.45 & 29.0 \\
\hline SM & 7.0 & 12.6 & 1.21 & 94.4 & 2.93 & 30.4 \\
\hline Significance & NS & $*$ & $*$ & $* *$ & $* *$ & NS \\
\hline LSD & & 1.31 & 0.17 & 11.14 & 1.04 & \\
\hline
\end{tabular}

a SM: Wheat straw mulching; TF: traditional flooding; PM: plastic film mulching. *** Represent significant at $P<0.05$ and 0.01 , respectively; NS, Not significant.

${ }^{\mathrm{b}}$ Least significant difference at the $5 \%$ level.

among the three cultivation systems, ranging from 6.8 to 7.6 and from 123 to $143 \mathrm{mg} \mathrm{kg}^{-1}$, respectively. SM resulted in a significant increase in soil organic $\mathrm{C}$, total $\mathrm{N}$, Olsen-P, and exchangeable $\mathrm{K}$ at $0-5 \mathrm{~cm}$ depth compared with TF. Soil organic C, total N, and exchangeable K at $0-5 \mathrm{~cm}$ depth under PM were similar to those under TF, but Olsen-P under PM (11.6 mg kg $\left.{ }^{-1}\right)$ was significantly higher than under TF $\left(8.2 \mathrm{mg} \mathrm{kg}^{-1}\right)$. Soil organic $\mathrm{C}$, Olsen-P, and exchangeable $\mathrm{K}$ at $5-12 \mathrm{~cm}$ depth showed similar trends to those at $0-5 \mathrm{~cm}$ depth but total $\mathrm{N}$ showed some differences. The positive effects of $\mathrm{SM}$ on the selected properties in the topsoil may have resulted from the return of wheat straw as a mulch material. Our results also indicate that PM has no negative effects on topsoil fertility.

At $12-24 \mathrm{~cm}$ depth, soil organic C, total and alkali hydrolyzable N, and Olsen-P under PM or SM were significantly higher than under TF. Soil 
$\mathrm{pH}$ and exchangeable $\mathrm{K}$ were similar among the three cultivation systems at $12-24 \mathrm{~cm}$ depth (Table 5). Non-flooded mulching cultivation had no effect on soil bulk density or soil porosity in the present study (data not shown).

\section{Discussion}

Effects of non-flooded mulching cultivation on rice grain yields were evident during the 5-year study period. In comparison to TF, PM led to higher average rice grain yields, perhaps because of its efficiency in maintaining soil moisture, increasing soil temperature at the early growth stages, and enhancing $\mathrm{N}$ transformations and availability (Liang et al., 1999; Liu et al., 2003; $\mathrm{Lu}$ and $\mathrm{Wu}, 2002$; Peng et al., 1999; Shi et al., 2002). Shen et al. (1997) reported that plastic film mulching cultivation produced larger and more vigorous root systems and increased early tillering of rice due to higher temperatures and this may also be one of the factors involved in increased grain yields. The finding that higher rice grain yields occurred under PM than under TF in the present study is strongly supported by other studies made in the same region (Fan et al., 2004, 2005; Liu et al., 2005) and in other regions of China (Fan et al., 2002; Liang et al., 1999; Shi et al., 2001; Wu et al., 1999). Lower surface soil temperatures at early stages of rice growth under SM (Parker and Larson, 1962; Wang et al., 2002) and $\mathrm{N}$ immobilization caused by the initial degradation of wheat residues as mulching materials (Jenkinson, 1985; Rao and Mikkelsen, 1976) may contribute to lowered available $\mathrm{N}$ and poor growth conditions for rice, with subsequent decreases in rice yields in the first three years. The similar rice grain yields among the three cultivation systems in the final two years indicate that rice grain yield responses to non-flooded straw mulching cultivation tended to be negative to neutral over time.

Rice yields ranged from 5.4 to $6.6 \mathrm{t} \mathrm{ha}^{-1}$ under TF and from 6.6 to $7.6 \mathrm{t} \mathrm{ha}^{-1}$ under PM in the present experiment, and no clear trends were found in TF or PM across the 5 years of the experiment (Table 1 and Figure 3). A recent analysis of yield trends in 27 long-term experiments conducted in different Asian countries suggests that stable rice yields of $5-6 \mathrm{tha}^{-1}$ in rice-based cropping systems seem to be common (Dawe et al., 2000; Dobermann and Witt, 2000). However, this trend has never been shown under plastic film mulching conditions. Stable rice grain yields under SM can also be attained as shown in Figure 3 and Table 1, but the average rice yield of SM is lower than of TF and PM. Thus, it is important to improve rice yield under SM through integrated nutrient management.

The data on nutrient uptake show that PM resulted in higher uptake of $\mathrm{N}$ and $\mathrm{K}$ by rice, suggesting that exhaustion of soil fertility, particularly $\mathrm{N}$ and $\mathrm{K}$, might occur under PM. However, the present results and those of Liu et al. (2003) have shown no differences in SOC, TN, or AN in the topsoil between PM and TF. This could be attributed to the $\mathrm{N}$ fertilizer application rates being sufficient to maintain rice productivity. Evidence from long-term experiments indicates that if input levels match crop requirements, it is possible to sustain soil fertility (Dobermann et al., 1998). However, the $\mathrm{N}$ fertilizer applied once as a basal application in the present study would not be conducive to efficient use of $\mathrm{N}$ and would need to be modified. One promising method might be to apply $\mathrm{N}$ based on plant demand and use tools such as the chlorophyll (SPAD) meter or the leaf color chart not only for TF (Balasubramanian et al., 1999; Dobermann et al., 2002), but also for PM and $\mathrm{SM}$. The negative $\mathrm{K}$ balance (Table 3 ) combined with the low soil $\mathrm{K}$ availability in the topsoil (Table 5) under both TF and PM suggests that higher $\mathrm{K}$ inputs from fertilizer, straw or manure may be necessary. However, the present study also indicates that exchangeable $\mathrm{K}$ may not be a suitable measure of plant-available $\mathrm{K}$ in this soil type in view of the relatively large plant $\mathrm{K}$ uptake (Table 2) and low internal efficiency of $\mathrm{K}$, despite low soil exchangeable $\mathrm{K}$ (Table 5).

SM significantly increased SOC at $0-5$ and 5$12 \mathrm{~cm}$ depths and TN at the $0-5 \mathrm{~cm}$ depth. This could be explained by the regular addition of slowly decomposing wheat straw as a mulching material resulting in organic matter and total $\mathrm{N}$ accumulation. Roper and Ladha (1995) reported that crop straw used as organic fertilizer stimulated biological $\mathrm{N}_{2}$-fixation in soil and may also have increased total N. A similar finding that crop residues on the soil surface increased organic $\mathrm{C}$ and total $\mathrm{N}$ in the top $5-15 \mathrm{~cm}$ of the 
soil profile was reported by Rasmussen and Collins (1991). SM also led to a net positive K balance and higher $\mathrm{K}$ availability in topsoil. We may therefore infer that the SM system is more sustainable than PM in terms of soil fertility and nutrient cycling, though the improvement in soil fertility in SM systems does not appear to lead to substantial increases in crop yield.

Increasing available soil $\mathrm{P}$ with regular $\mathrm{P}$ addition through fertilizers would be expected because rice utilizes only a fraction of the applied P. Moreover, wheat straw as a mulching material also supplied considerable amounts of $\mathrm{P}$ to the soil (Table 3). Perhaps because of this, a greater build-up of available $\mathrm{P}$ in topsoil occurred under SM compared with PM or TF. However, the present results differ from the finding of $\mathrm{Hu}$ et al. (1999) that available P in PM was lower than in TF. Lower available $\mathrm{P}$ in TF in this context may be explained by higher $\mathrm{P}$ removal in TF during the fifth rice season (uptake by rice) (Figure 4), leading to a subsequent decrease in available $\mathrm{P}$. The rice plots were drained about 15 days before the soil samples were collected in the present study and this may have led to some re-adsorption or precipitation of soluble $\mathrm{P}$ (Cheng and Cao, 1997; Kirk et al., 1990; Ponnamperuma, 1972) and this may be an additional factor contributing to the lower available $\mathrm{P}$ in TF.

Wetland rice can derive a significant part of its nutrient requirements from the subsoil. Sekiya and Shiga (1977) reported an $\mathrm{N}$ contribution from the subsoil to total $\mathrm{N}$ uptake by rice of up to $5-35 \%$ in zero $N$ treatments and $14-22 \%$ in $\mathrm{N}$ fertilizer treatments. Chen and Zhu (1986) recorded a subsoil contribution of $16-49 \%$ to the total soil $\mathrm{N}$ supply to rice plants in the Tai Lake region of east China. The higher observed SOC, $\mathrm{TN}, \mathrm{AH}-\mathrm{N}$ and OP in the12-24 cm layer under PM or SM compared with TF in the present study may be ascribed to lower nutrient removal from the subsoil under non-flooded mulching cultivation than under traditional flooding cultivation because rice roots are distributed mainly in the topsoil under non-flooded conditions (Liang et al., 2000; Wang, 2001). This suggests that rice plants under continuously non-flooded mulching conditions may fail to utilize nutrients efficiently from the subsoil. However, to what extent the subsoil nutrients contributed to total nutrient uptake by rice in the three cultivation systems (TF, PM, and SM) cannot be determined unequivocally on the basis of the data available.

In conclusion, results from this study indicate that PM led to increased rice grain yields and system productivity and stable crop yields were attained over time. It seems that soil fertility can be sustained under PM if input levels match plant requirements. SM is also an alternative option of rice plant cultivation for farmers using $\mathrm{R}-\mathrm{W}$ rotations in view of its efficiency in saving water, improving soil fertility, and maintaining system productivity. There is a need to evaluate the long-term environmental risks (e.g. soil pollution by plastic film if recycling of used plastic film were not properly practiced and greenhouse gas emissions) and economics of non-flooded mulching cultivation and improved system productivity by integrated resource management.

\section{Acknowledgements}

We thank the Major State Basic Research Development Programme of the People's Republic of China (Grant No. G1999011707), the Major Research Programme of the Chinese Ministry of Education (Grant No. 0112), and the 948 Major International Cooperation Programme of the Chinese Ministry of Agriculture (Grant No. 202003-Z53) for generous financial support.

\section{References}

Balasubramanian V, Morales A C, Cruz R T and Abdulrachman S 1999 On-farm adaptation of knowledge-intensive N management technologies for rice systems. Nutr. Cycl. Agroecosyst. 53, 59-69.

Bouman B A M 2001 Water-efficient management strategies in rice production. Int. Rice Res. Notes 26, 17-22.

Chen D L and Zhu Z L 1986 Nitrogen supply of subsoil in flooded rice field. Soils 18, 33-34(in Chinese).

Cheng C M and Cao C Y 1997 Transformation and availability of inorganic phosphorus in calcareous soils during flooded and draining alternating process. Acta Pedolo. Sin. 34, 382391 (in Chinese).

Cornfield A H 1960 Ammonia released on treating soils with $\mathrm{N}$ sodium hydroxide as a possible means of predicting the nitrogen-supplying power of soils. Nature 187, 260-261.

Dawe D, Dobermann A, Ladha J K, Yadav R L, Lin B, Gupta R K, Lal. P, Panaullah G., Sariam O, Singh Y, Swarup A and Zhen Q X 2003 Do organic amendments improve yield trends and profitability in intensive rice systems?. Field Crops Res. 83, 191-213. 
Dawe D, Dobermann A, Moya P, Abdulrachman S, Lal P, Li S Y, Lin B, Panaullah G, Sariam O, Singh Y, Swarup A, Tan P S and Zhen Q X 2000 How widespread are yield declines in long-term rice experiments in Asia?. Field Crops Res. 66, 175-193.

Dobermann A and Fairhurst T H 2000 Rice: nutrient disorders and nutrient management. PPI and IRRI, Singapore, Makati City 34-37 pp.

Dobermann A and Witt C 2000 The potential impact of crop intensification on carbon and nitrogen cycling in intensive rice systems. In Carbon and Nitrogen Dynamics in Flooded Soils. Eds. G J D Kirk and D C Olk. pp.1-27. Proceedings of the Workshop on Carbon and Nitrogen Dynamics in Flooded Soils, 19-22 April 1999, Los Baños, Philippines. International Rice Research Institute, Makati City (Philippines). 188 pp.

Dobermann A, Cassman K G, Mamaril C P and Sheehy J E 1998 Management of phosphorus, potassium, and sulfur in intensive irrigated lowland rice. Field Crops Res. 56, 113138.

Dobermann A, Witt C, Dawe D, Abdulrachman S, Gines H C, Nagarajan R, Satawathananont S, Son T T, Tan P S, Wang G H, Chien N V., Thoa V T K, Phung C V, Stalin P, Muthukrishnan P, Ravi. V, Babu M, Chatuporn S, Sookthongsa J, Sun Q, Fu R, Simbahan G. C and Adviento M A A 2002 Site-specific nutrient management for intensive rice cropping systems in Asia. Field Crops Res. 74, 37-66.

Fan M S, Jiang R F, Liu X J, Zhang F S, Lu S H, Zeng X Z and Christie P 2005 Interactions between non-flooded mulching cultivation and varying $\mathrm{N}$ inputs in rice-wheat rotations. Field Crops Res. 91, 307-318.

Fan M S, Liu X J, Jiang R F, Zhang F S, Lu S H and Zeng X Z 2004 Effects of non-flooded mulching cultivation and $\mathrm{N}$ rates on productivity and $\mathrm{N}$ utilization in rice-wheat cropping systems. Acta Ecol. Sin. 24, 2591-2596 (in Chinese).

Fan X L, Zhang J P and Wu P 2002 Water and nitrogen use efficiency of lowland rice in ground covering rice production system in south China. J. Plant Nutr. 25, 1855-1862.

Haefele S M, Wopereis M C S, Ndiaye M K, Barro S E and Ould Isselmou M 2003 Internal nutrient efficiencies, fertilizer recovery rates and indigenous nutrient supply of irrigated lowland rice in Sahelian West Africa. Field Crops Res. 80, 19-32.

Hu F, Yang M, Liang Y, Liu M and Chen X 1999 A study on fertility characteristics of paddy soils under plastic film mulching condition. In Soil Science Towards the 21st Century (Jiangsu Vol.). Ed. Soil Committee of Jiangsu Province. pp. 213-215. Hehai University Press, Nanjing, China (in Chinese)

Jenkinson D S 1985 How straw incorporation affects the nitrogen cycle. In Straw, Soil and Science. ed. J Hardcastle. pp. 14-15. AFRC, London.

Kirk G J D, Yu T R and Choudhury F A 1990 Phosphorus Requirement for Sustainable Agriculture in Asia and Oceania. International Rice Research Institute, Los Baños, Philippines 211-221 pp.

Lefroy R D B, Chaitep W and Blair G J 1994 Release of sulfur from rice residue under flooded and nonflooded soil conditions. Aust. J. Agric. Res. 45, 657-667.

Liang Y C, Hu F, Shen Q R, Lu S H, Wu L H and Zhang F S $2000 \mathrm{An}$ overview of rice cultivation on plastic film mulched dryland. In Studies on Plant Nutrition - Progress and Overview. eds. F Feng., F S Zhang. \& X Q Yang. pp. 114-
127. China Agricultural University Press, Beijing, China (in Chinese).

Liang Y C, Hu F, Yang M C, Zhu X L, Wang G P and Wang Y L 1999 Methods for increasing yield and irrigation water use efficiency of rice using plastic film mulch. Sci. Agric. Sin 32, 26-32(in Chinese).

Liu X J, Ai Y W, Zhang F S, Lu S H, Zeng X Z and Fan M S 2005 Crop production, nitrogen recovery and water use efficiency in rice-wheat rotation as affected by non-flooded mulching cultivation (NFMC). Nutr. Cycl. Agroecosyst. 71, 289-299.

Liu X J, Wang J C, Lu S H, Zhang F S, Zeng X Z, Ai Y W, Peng S B and Christie P 2003 Effects of non-flooded mulching cultivation on crop yield, nutrient uptake and nutrient balance in rice-wheat cropping systems. Field Crops Res. 83, 297-311.

Lu X H and Wu L H 2002 The utilization of nitrogen, phosphorous and potassium for film mulched rice. Chinese J. Soil Sci. 33, 421-424(in Chinese).

Maclean J L, Dawe D C, Hardy B and Hettel G P 2002 Rice almanac. Los Baños (Philippines): International Rice Research Institute, Bouaké (Côte d' lvoire): West Africa Rice Development Association, Cali (Colombia): International Center for Tropical Agriculture, Rome (Italy): Food and Agriculture Organization. pp. 1-10.

Parker D T and Larson W E 1962 Nitrification as affected by temperature and moisture content of mulched soils. Soil Sci. Soc. Am. Proc. 26, 238-242.

Peng S, Shen K, Wang X, Liu J, Luo X and Wu L 1999 A new rice cultivation technology: plastic film mulching. Int. Rice Res. Notes 24, 9-10.

Ponnamperuma F N 1972 The chemistry of submerged soils. Adv Agron. 24, 29-96.

Ponnamperuma F N 1984 Organic Matter and Rice. IRRI, Los Baños, Philippines 117-136 pp.

Raison R J 1979 Modification of the soil environment by vegetation fires, with particular reference to nitrogen transformations: a review. Plant Soil 51, 73-108.

Rao D N and Mikkelsen D S 1976 Effect of rice straw incorporation on rice plant growth and nutrition. Agron. J. $68,752-755$.

Rasmussen P E and Collins H P 1991 Long-term impacts of tillage, fertilizer, and crop residue on soil organic matter in temperate semi-arid regions. Adv Agron. 45, 93-134.

Roper M M and Ladha J K 1995 Biological $N_{2}$ fixation by heterotrophic and phototrophic bacteria in association with straw. Plant Soil 174, 211-224.

SAS 1996 SAS/STAT User's guide. 6SAS Institute Inc, Cary, NC, USA.

Sekiya S and Shiga H 1977 A role of subsoil of paddy field in nitrogen supply to rice plants. J. Agron. Res. Quar. 11, 95100.

Shen K, Wang X and Luo X 1997 Test and demonstration on wet-cultivation with film mulching of rice. Hubei Agric. Sci. $5,18-22$ (in Chinese).

Shi X J 2003 Characteristics of nutrient cycling in the ricewheat rotation system. Ph.D. Dissertation, China Agricultural University (in Chinese with English abstract), Beijing, China. pp. 104-114.

Shi Y, Shen Q R, Mao Z S and Li W 2002 Biological response of rice crop cultivated on upland soil condition and the effect of mulching on it. J. Plant Nutr. Fert. Sci. 7, 271-277 (in Chinese) 
Shi Y, Shen Q R, Mao Z S and Xu G H 2001 Time and horizontal spatial variations of $\mathrm{NH}^{4+}-\mathrm{N}$ and $\mathrm{NO}^{3-}-\mathrm{N}$ of rhizospheric soil with rice cultivation on upland condition mulched with half-decomposed rice straw. Sci. Agric. Sin. 35, 520-524 (in Chinese).

Sparks D L, Page A L, Johnston C T and Summer M E 1996 Methods of Soil Analysis Part 3. Chemical Methods. SSSA Book series No. 5. SSSA, Madison, WI 1085-1121 pp.

Wang J C 2001 Crop yields and nutrient dynamics impacted by different mulching styles in upland rice-wheat rotation systems. Ph.D. Dissertation, China Agricultural University (in Chinese with English abstract), Beijing, China. pp. 26-31.

Wang J C, Liu X J, Zhang F S, Cao Y P, Lu S H and Zeng X Z 2002 The effect of different soil mulch materials on the growth and yield of rice. Acta Ecol. Sin. 22, 922-929 (in Chinese).

Witt C, Dobermann A, Abdulrachman S, Gines H C, Wang G $\mathrm{H}$, Nagarajian R, Satawathananont S, Son T T, Tan P S, Tiem L V, Simbahan G C and Olk D C 1999 Internal nutrient efficiencies of irrigated lowland rice in tropical and subtropical Asia. Field Crops Res. 63, 113-138.

Wu L H, Zhu Z R, Liang Y C, Shi W Y and Zhang L M 1999 The development of the rice film mulching cultivation. J. Zhejiang Agric. Univ. 25, 41-42.

Section editor: H. Lambers 